\title{
The Conservation Strategy of "Kampung Melayu Darat” As Historical Area in Semarang City
}

\author{
Suzanna Ratih Sari ${ }^{*}$, Eko Punto Hendro ${ }^{* *}$, Hermin Werdiningsih ${ }^{* * *}$ \\ * Department of Architecture, Diponegoro University \\ ${ }^{* *}$ Department of Historical Science, Diponegoro University \\ Department of Architecture, Diponegoro University
}

DOI: 10.29322/IJSRP.8.6.2018.p7869

http://dx.doi.org/10.29322/IJSRP.8.6.2018.p7869

\begin{abstract}
Semarang City is well known as one of coastal city which has some historical values. One of the areas that has so many historical value is so called "Kampung Melayu Darat”. Formerly, "Kampung Melayu Darat” was the oldest "Kampung” in Semarang City. But the current condition is now very poor. The "kampung" is suffered by flood which caused some damages to the existing heritage housings and buildings. Considering to that matter and the important history of "Kampung Melayu Darat" especially for Semarang City, researcher wants to study about how to create suitable concept and strategy of conserving "Kampung Melayu Darat" as one of traditional "kampung" in Semarang. By using descriptive method, researcher wants to describe the potentials and problems existed in the kampoong and try to analyze the proper conservation concept and strategy for increasing the value of "Kampung Melayu Darat”.
\end{abstract}

Index Terms- About four key words or phrases in alphabetical order, separated by commas. Keywords are used to retrieve documents in an information system such as an online journal or a search engine. (Mention 4-5 keywords)

\section{INTRODUCTION}

$\mathrm{T}$ he establishment of cultural heritage area in Kampung Melayu Darat that located at 6057'58.4”S 110025'19.4”E. is based on the boundaries that refers to areas which have highly historical values both on tangible and intangible. The boundaries / deliniations of the area are:

North : Kakap Road,

Southern : Dorang Road,

East : Jalan Layur,

West : Jalan Kakap and Jalan Tambra.

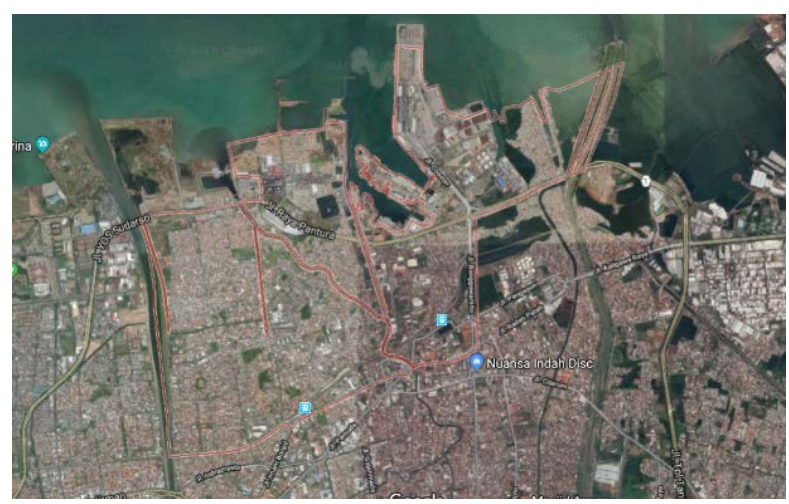

FIGURE 1 . Picture of Kecamatan Semarang Utara Source : Google Maps. 


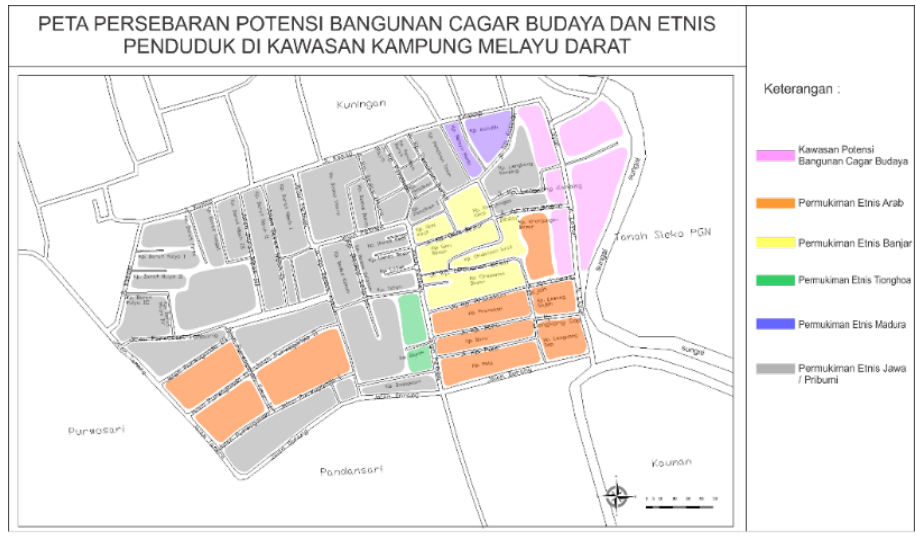

FIGURE 2. Picture of Kampung Melayu Darat Source : Private Document

Kampung Melayu Darat was consisted by various ethnicities. They are Arabic, Banjar, Chinese, Madura, and Javanese Ethnics. The Village of Arabic Ethnics is Kampung Pulo, Kampung Baru, Kampung Pranakan, Kampung Lengkong Sop, Kampung Lawang Gajah, and Kampung Kranjangan Besar. In addition there are also some Arabics who live in Purwogondo. The Ethnic of Banjar occupies the Great Cirebonan Village, Kampung Cirebonan Kecil, Kampung Geni Besar, Kampung Geni Kecil, and Kampung Kranjangan Kecil. There are not many ethnic Chinese who live in this Kampung Melayu Darat, only a few of them are living in Pethek Road. Ethnic Madura occupies Kampung Kalicilik and Kampung Melayu Manis. While many ethnic Javanese spread in this Kampung Melayu Darat.

“Kampung Melayu Darat” has highly historical values. "Kampung Melayu Darat” is one of the former historical village, which is now a merger from the Melayu Village itself, Arab Village (Pecinan), Banjar Village and some other ethnic villages. The word 'Darat' (land), relates to Kiai Sholeh Darat figure, a famous scholar who lived during the dutch colonial era on the 19th century. According to some sources, he was the teacher of the famous figure such as Kartini and Kyai Hasyim Ashari. His grave is in a Bergota public cemetery. The historical village needs to be preserved, ecpecially to support the existance of Semarang Old City which is now on the list of world heritage by UNESCO.

Based on Semarang City history, it was mentioned that Ki Pandan Arang was the first regent of Semarang. In "Serat Kandaning Ringgit Purwa” manuscript no. 7, it was stated that he was the son of Sabrang Lor Prince, the grandchildren of Panembahan Demak. Sunan Bonang assigned him to open a human settlement in Pulo Tirang area, in Tirang Amper to Islamize the people around it. That event happened between 1470 until 1480's.

The existence of Ki Ageng Pandan Arang in Bubakan mentioned by Soekirno on his book, Semarang as follows:

“... Prince Pandan Arang who followed the trace of his father, keep expand his influence among the society. Then, in 1575 he was appointed to become the first regent of Semarang, and the district was located on Bubakan Village (the former Landraad Building)... “ (Soekino, 1956:28).

Started at 1756, the capital of Semarang was moved to Kampung Kauman area which marked by the establishment of Masjid Besar Kauman (Kauman Great Mosque) at that year which located on the west side of the town square. But before, in the late 17th century, with the permission of Mataram King, VOC has built lodges or Vijhoek fortress which located not far from Kauman Great Mosque. With the moved of Semarang district government from region to region, started from Bubakan Area to Kauman Village. It also shows the increasment of human settlement in Semarang City, then coupled with the presence of VOC’s lodges.

Since the Ki Ageng Pandanaran I reign, until the Dutch Colonial period, Semarang City including Kampung Melayu Darat was keep growing. In this development, the human settlement also developed by forming clusters. However, the cluster was unique because it was concentrated mainly by ethnic, profession, religion and positions. And Kampung Melayu Darat become more unique, because it concentrated on the center traditional government (Kauman) and the center of dutch settlement in Semarang Old City.

\section{LITERATURE REVIEW}

\section{Conservation and Development}

Conservation is an effort to conserve the environment, but still keep the benefits that can be gained at that time while maintaining the existence of every component of the environment for future utilization. According to Adishakti (2007) the term conservation commonly used by architects refers to the Charter for the Conservation of Places of Cultural Significance, Burra, Australia, referring 
to the Charter for the Conservation of Places of Cultural Significance, Burra, Australia. Conservation is the concept of the process of managing a place or space or object so that the cultural meaning contained in it is well preserved. Conservation activities cover all maintenance activities in accordance with local conditions and situations as well as development efforts for further utilization.

A conservation program should not only be maintained for its authenticity and maintenance at all but does not bring economic value or other benefits to the owner or the wider community. In this case the role of architect is very important in determining the appropriate function because not all functions can be included. These activities require cross-sectoral, multi-dimensional and disciplined, and sustainable efforts.

The Criteria for determining the proper object according to Eko Budihardjo are to conserve according the aesthetic aspect, plurality, rarity, historical role, privileges and to improve the quality and image of the surrounding environment. Another consideration which is based on the motivation to maintain the cultural and historical heritage; realization motivation varied from architectural, aesthetic; economic motivation to make conserved buildings as an object that can increase the value of the environment; symbolic motivation ethnic and cultural developments that have lived in the neighborhood and his city (Eko Budihardjo, 1986).

In order to develop the identity of Semarang city with regard to the historical aspects, Semarang government can make the concept of conservation of the Old wider city. It should be a conservation area a city like Semarang Old City not only in the Old Town area, but also in other places such as the Kauman village, Chinatown, Pekojan village, Sekayu village, Johar traditional market and others. The consideration that these regions constitute the historical district downtown in the past. The results of the study is how to construct concept strategy for conserving Semarang Old City as one of the worthiest historical area in Semarang. The concept would then use as a basic to release Commendment on the conservation area of Semarang, and consequently would be so any attempt on renovation, construction or even demolition of buildings in the conservation area that must be recommended by the Government of Semarang and Archaeological Heritage Preservation. In order realize Semarang Old city, the strategy should also involve local group of people that can assist local government to conserve Semarang Old City by empowering all of the potentials of Semarang Old City such as arts, culture, culinary or another, distinct and nuanced past. Furthermore, the tourism actors are also encourage to capture this moment as tourism attraction that must be promoted. If this concept can be realized, then Semarang Old City will have a unique identity, which can be enjoyed by every citizen and become of the proudness of the city.

\section{Theory of "Kampung"}

Based on several studies on villages in addition to having some similarities about the condition of the village where the village always develops unplanned. Even the development of kampung in the city aims as a "container" of adaptation for rural people who live in the city with all sorts of rituals and cultures that are still firmly held from their respective ancestors. The existence of villages in urban areas that tend to be close to the various centers of activity in terms of existence (legality) there is a dualism of the developing village is not in accordance with the designation and the village that develops in accordance with the designation of urban spatial layout. Villages that develop in accordance with urban spatial layout and legality become one of the urban elements that act as residential providers for various layers of society due to the influence of globalization.

\section{The Preservation theory of "Kampung"}

Village conservation theory is using the concept of revitalization development. In the great Indonesian dictionary, Revitalization means the processes, means, and deeds of reviving a thing that was previously less powerless. Actually revitalization means to make something or act becomes vital. While the word vital has a very important meaning or very necessary (for life and so on). Understanding through other languages of revitalization may mean processes, means, and or actions to revive or reenforce any program of activity. Or more clearly revitalization is to revive vitality. Thus, the meaning of this revitalization in general is the efforts to make something that becomes important and very necessary.

The revitalization includes conservation-preservation as part of urban design efforts to preserve the past cultural heritage of historical and aesthetic-architectural value. Or precisely is the effort to preserve the built environment in order to remain in its original condition and prevent the occurrence of damage process. Depending on the condition of the built environment to be preserved, this effort is usually accompanied also by restoration, rehabilitation and / or reconstruction efforts. So, revitalization is an effort to revitalize an area or part of the city that was once vital / alive, but then decline / degradation. In addition, revitalization is the activity of modifying an environment or cultural heritage object for new usage. Physical revitalization is believed to improve the physical condition (including the public spaces) of the city, but not for the long term. For that, still needed improvement and increase economic activity (economic revitalization) which refers to social-cultural aspect as well as environmental aspect (environmental objectives). This is absolutely necessary because through productive use, it is hoped that a lasting mechanism of care and control will be built on urban facilities and infrastructure. 


\section{RESEARCH METHODS}

Methodology used in this study is references study, observation, direct interview, and Focus Group Discussion (FGD). The target group would be consisted of local community, culinary vendor, local leader, related institution, and local group of people.

Another method used in the discussion is qualitative method. This qualitative method is actually based on the real condition of the study, therefore the data that had already been gathered will be described qualitatively based on the existing condition.

\section{DISCUSSION}

The potential of cultural heritage in Kampung Melayu area mostly takes form of heritage buildings from Indis era and these buildings are mostly found along Layur Road, Kampung Melayu Darat. These buildings are uninhabited buildings and some of them formerly used as warehouses. However, there are also buildings with cultural heritage potential in the form of worship houses, Colonial Building, and Traditional Houses of various ethnic.

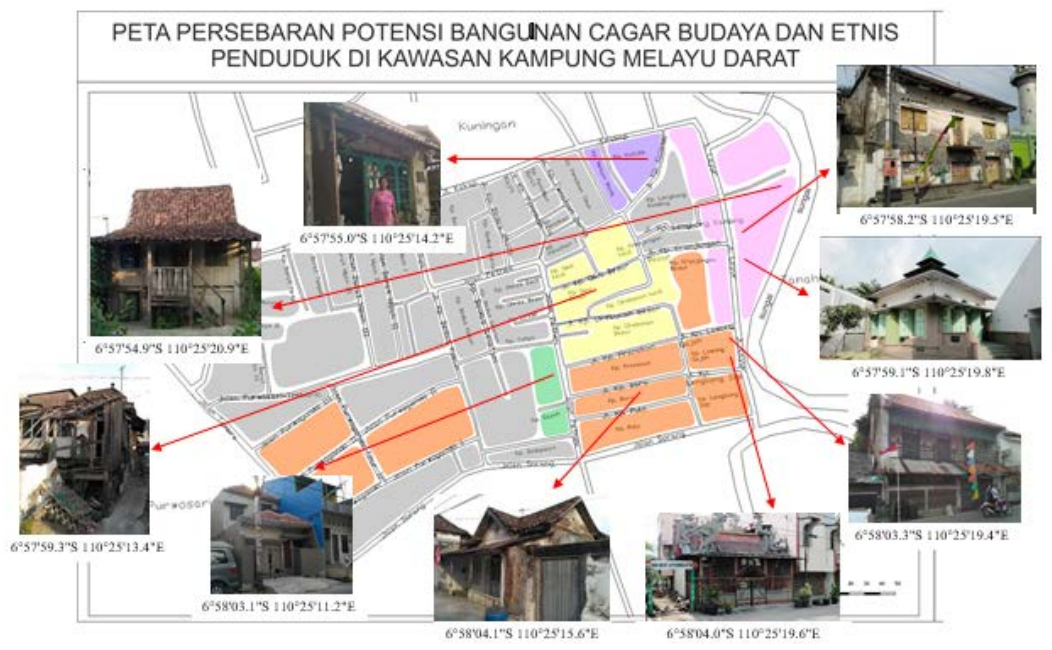

FIGURE 3. Distribution Map on potential of cultural heritage buildings in Kampung Melayu Darat Source : Private Document

Layur Mosque as shown above is a worship building from an Indis era, and it is known as the tower mosque. This building has been registered as a cultural heritage building since 1992. The tower was formerly a harbor monitoring tower at Indis era. Layur Mosque is one of the oldest mosques in Semarang with a great historical value. Due to the uniqueness of the building, the building with Chinese architecture is very easy to be identified, especially from characteristics of the existing styles. The hallmark of Chinese architecture is its emphasis on articulation and bilateral symmetry, which means balance. Chinese classical buildings, especially those owned by the rich are built with an emphasis on the width rather than on the height. Chinese architecture emphasizes more on the visual impact of the building width.
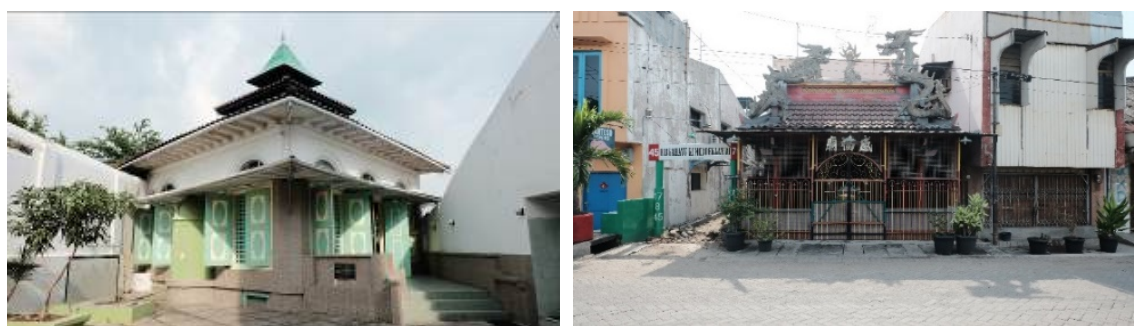

FIGURE 4. The main building of Layur Mosque and Kam Hok Bio Hok Tik Tjing Sien temple

(Source: Private Documents)

The mixing culture, making Indis architecture in Indonesia with local architecture or known as Indis architecture becomes a unique cultural phenomenon. The term Indis is derived from the term 'Nederlandsch Indie' or Dutch East Indies in Indonesian. The Dutch first came to Indonesia in 1619. They originally came to Indonesia for trading but later monopolized through the VOC and eventually became the ruler until the arrival of Japan in 1942. The presence of Dutch people for three centuries in Indonesia certainly changes many aspects of life. The changes, among others, are found on the art of building or architecture.

A house of Indis style at a glance looks like a traditional building with a roof of Joglo Limasan shape. Generally the building is tall and has many windows. The influence of Western culture is seen on large pillars, Italian hanging lights mounted on the front porch 
giving a grand look to the house, especially at night. The door is located right in the middle part flanked with large windows on the left and right sides. There is a large mirror with a porcelain statue laid in between the windows and doors. The Dutch, planters, priyayi and indigenous peoples who have attained higher education are classified into top societies, contributing to the spread of Indis culture through a lavish lifestyle.
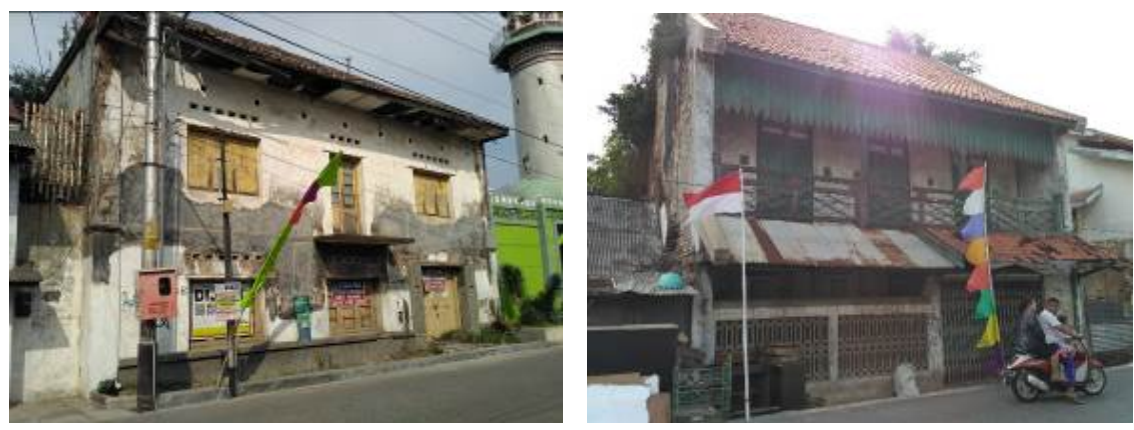

FIGURE 5. The Indische building in Layur Road (Source: Private Documents)

The classification of traditional buildings are based on several ethnicities living in Kampung Melayu Darat, mostly in the form of Javanese Traditional Houses distributed in all areas of Kampung Melayu Darat. In addition to Javanese traditional houses, there are also traditional house of other ethnicities who live in Kampung Melayu Darat, including Banjar, Arabic, Chinese, and Madurese ethnic houses.

Banjar ethnic house can be found in Kampong Cirebonan Besar, Kampung Cirebonan Kecil, Kampung Geni Besar, Kampung Geni Kecil, and Kampung Kranjangan Kecil. It is called Banjar house because the major tribes lived in South Kalimantan is Banjar tribe. Banjar people in South Kalimantan actually have a high artistic soul. One of them is reflected in visual arts as seen in the various ornaments or decorations found in Banjar traditional houses, also in mosque ornaments and other facilities, such as sasirangan traditional cloth, dinding airguci, women sarong (tapih); gravestone, tutujah (rice cultivation tool), ranggaman (cutting rice knife), panginangan (place of whiting), bath dipper, etc. Ornaments of Banjar houses can be found, among others, in several types of buildings, such as Rumah Bubungan Tinggi (Rumah Baanjung), Gajah Baliku, Gajah Manyusu, Palimasan, Palimbangan, Balai Laki, Balai Bini, Tadah Alas, Cacak Burung / Anjung Surung. Ornaments in Banjar architecture as a sculpture work has a special character in each type of Banjar house, hence decorations that are found in the Bubungan Tinggi house is not always similar to the type of Palimbangan house. Similarly, the ornaments found on the type of Gajah Baliku house also different with the existing ornaments found on the type of Burung Cacak or Anjung Surung house. However, there is also a variety of neutral ornamental sculpture, meaning there is a placement of these various ornaments on almost all types of Banjar traditional houses.

From the above characteristics, there are some Banjar houses that can be identified in Kampung Melayu Darat as seen in the picture below. Banjar House with Bubungan Tinggi type is dominantly found in this Kampung Melayu Darat. While the term Bubungan Tinggi house refers to the shape of the house itself which has a high and taper roof to form a 45-degree angle (see Figure 3.29).

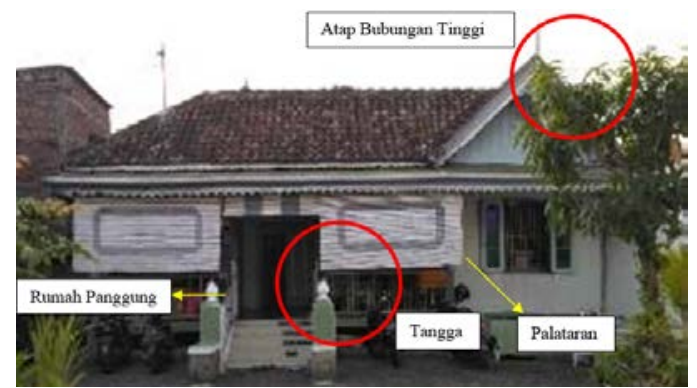

FIGURE 6. Rumah Panggung owned by one of Melayu Darat villagers (Source: Private Documents) 


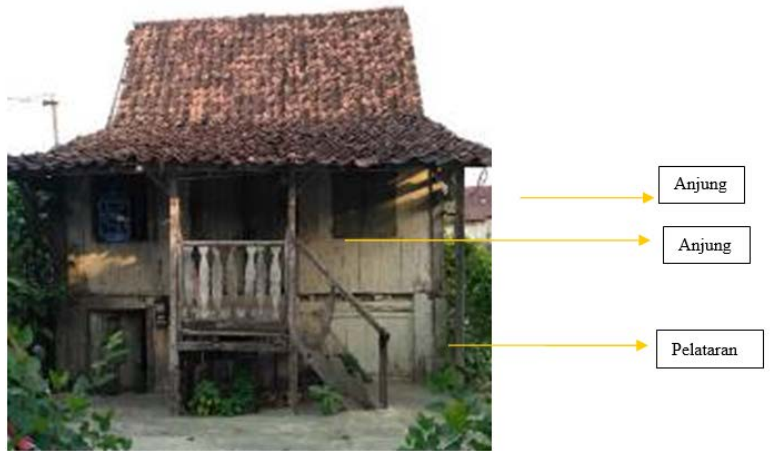

FIGURE 7. Rumah Panggung owned by one of Melayu Darat villagers

(Source: Private Documents)

People of Arab ethnic also live in Kampung Melayu Darat. Most of them occupy Kampung Baru, Kampung Pulo, Kampung Lengkong Gajah, and Kampung Lengkong Sop areas. However, there are also some of them who live in Pethek Road and Purwogondo II.
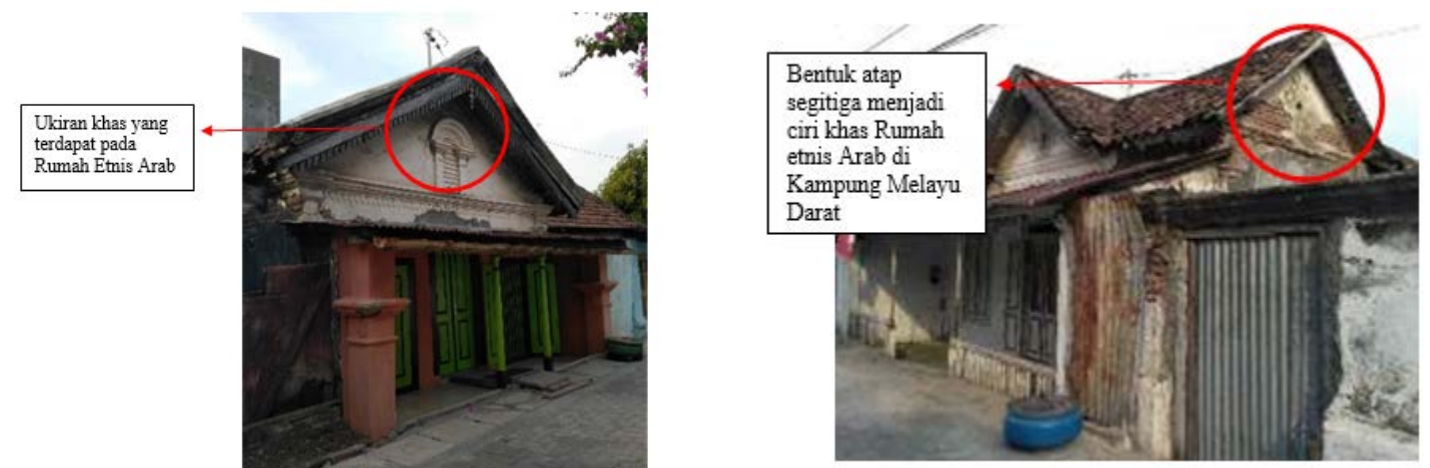

FIGURE 8. House of Arab Ethnic citizens in Kampung Melayu Darat

(Source: Private Documents)

There are only a few Chinese ethnic living in Kampung Melayu Darat. Their traditional homes are rarely found because most of their homes are newly built houses. Chinese people who are living in these settlements only about $20 \%$ and some of them live in Pethek Road. They generally work as traders. Nevertheless, there is still a relic of ancient Chinese ethnic in Kampung Melayu Darat as a proof that once there was a Chinese society, that is an ancient temple (klentheng) located in Layur road.

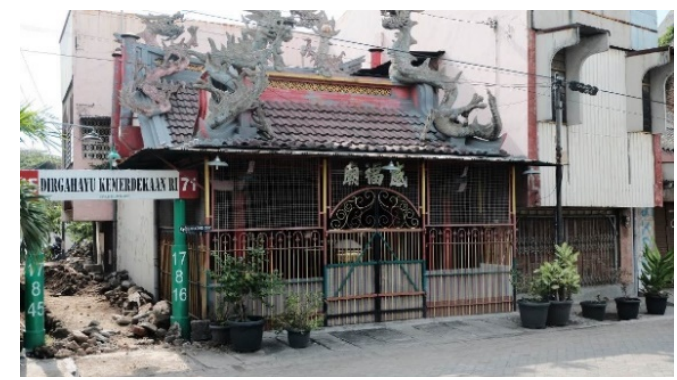

FIGURE 9. The Religious Building of Chinese Ethnic citizens in Kampung Melayu Darat

(Source: Private Documents)

The design of Madurese traditional house is called Taneyan Lanjang. This name is actually taken from the name of Kampung Madura itself. Kampung Madura consists of several traditional houses that located in an area. This village is usually inhabited by those in close kinship or family. Characteristic of Madurese house is a strong traditional style without wall separator (partition) in the inside room. The construction of the house is made of wood along with building materials which are generally taken from the natural surroundings. Generally Madurese traditional house is built giving on to the north, south, or facing toward the sun. The door position in Madurese ethnic house is not so emphasized, sometimes in the side or back of the house. While windows are generally not found or houses are built without windows or other ventilation. The influence of Islam in Madurese traditional house is can seen with the existence of 
langgar (small mosque) in almost all houses, while the Chinese influence is seen from various sea dragon ornaments placed at the entrance of the house.

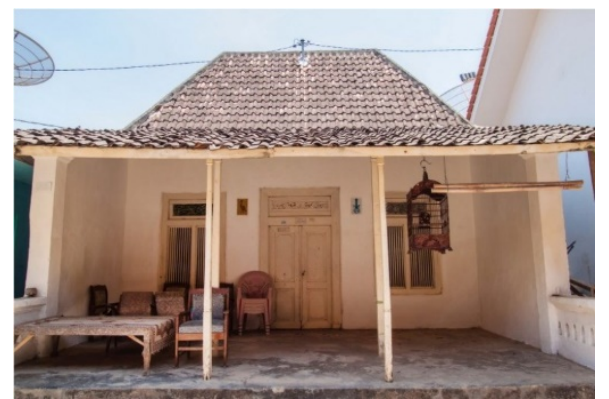

FIGURE 10. Example of Madurese Ethnic House

(Source: http://www.lihat.co.id/properti/design-rumah-adat-madura.html)

The number of Madurese ethnic houses that are found in Kampung Melayu is very limited. The existing Madurese ethnic house today has been adapted to the surrounding environment, so it is no longer referring to the Madurese architectural principles.

From the description about Kampung Melayu Darat, it can be concluded that Kampung Melayu Darat is a multi-ethnic village in Semarang city. This village has a strong connection with Arab, Chinese, and Javanese with a background that is reflected on the remains of its historical and toponym sides. Kampung Melayu Darat as one of the conservation areas in Semarang city is also become a cultural heritage that needs to be sought for its preservation. This is related to many objects of cultural heritage which are existed until today either in a minor until heavily damaged conditions and even destroyed without any trace.

Problems and potentials analysis of the research results on each ethnic found in Kampung Melayu Darat are can be seen in the table below:

Table of Problems and Potentials Analysis

\begin{tabular}{|c|c|c|c|c|}
\hline \multirow{2}{*}{$\begin{array}{l}\text { Name of } \\
\text { Region }\end{array}$} & \multicolumn{2}{|c|}{ Potentials } & \multirow{2}{*}{ Problems } & \multirow{2}{*}{ Recommendations } \\
\hline & Tourism & Cultural Heritage & & \\
\hline \multirow[t]{3}{*}{\begin{tabular}{|l|} 
Kampung \\
Banjar
\end{tabular}} & $\begin{array}{l}\text { Banjar ethnic } \\
\text { house area }\end{array}$ & $\begin{array}{ll}\begin{array}{l}\text { Banjar } \\
\text { house }\end{array} & \text { ethnic } \\
\end{array}$ & \begin{tabular}{|lr} 
Limited facilities and \\
infrastructure
\end{tabular} & $\begin{array}{l}\text { The requirement of integrated facilities } \\
\text { and infrastructure with other villages }\end{array}$ \\
\hline & & & $\begin{array}{l}\text { Lack of socialization about } \\
\text { cultural heritage buildings }\end{array}$ & $\begin{array}{l}\text { Socialization for the local community } \\
\text { is required }\end{array}$ \\
\hline & & & $\begin{array}{l}\text { Inadequate promotion for the } \\
\text { village }\end{array}$ & $\begin{array}{l}\text { The government must help to give } \\
\text { promotion }\end{array}$ \\
\hline \multirow[t]{3}{*}{$\begin{array}{l}\text { Kampung } \\
\text { Arab } \\
\end{array}$} & Culinary village & Arab ethnic house & $\begin{array}{ll}\text { Limited facilities and } \\
\text { infrastructure }\end{array}$ & $\begin{array}{l}\text { The requirement of integrated facilities } \\
\text { and infrastructure with other villages }\end{array}$ \\
\hline & $\begin{array}{l}\text { Religious } \\
\text { Tourism }\end{array}$ & & $\begin{array}{l}\text { Lack of socialization about } \\
\text { cultural heritage buildings }\end{array}$ & $\begin{array}{l}\text { Socialization for the local community } \\
\text { is required }\end{array}$ \\
\hline & & & $\begin{array}{l}\text { Inadequate promotion for the } \\
\text { village }\end{array}$ & $\begin{array}{l}\text { The government must help to give } \\
\text { promotion }\end{array}$ \\
\hline $\begin{array}{l}\text { Kampung } \\
\text { China }\end{array}$ & $\begin{array}{l}\text { Cultural Tourism } \\
\text { of } \quad \text { Little } \\
\text { Poo }\end{array}$ & Pagoda / temple & $\begin{array}{l}\text { Inadequate promotion } \\
\text { tourism and temple }\end{array}$ & $\begin{array}{l}\text { The government must help to give } \\
\text { promotion }\end{array}$ \\
\hline \begin{tabular}{|l|} 
Kampung \\
Madura
\end{tabular} & - & - & $\begin{array}{l}\text { The number of Madurese ethnic } \\
\text { is getting less }\end{array}$ & \\
\hline \multirow[t]{3}{*}{ Layur Road } & $\begin{array}{l}\text { Layur Mosque } \\
\text { Tourism Area }\end{array}$ & Layur Mosque & $\begin{array}{l}\text { The less integrated facilities } \\
\text { and infrastructures with other } \\
\text { areas }\end{array}$ & $\begin{array}{l}\text { The need of integrated facilities and } \\
\text { infrastructure with the nearest cultural } \\
\text { heritage areas, for example kota lama } \\
\text { (old city). }\end{array}$ \\
\hline & $\begin{array}{l}\text { Indis buildings } \\
\text { tourism area }\end{array}$ & Indis buildings & $\begin{array}{l}\text { Inadequate promotion for the } \\
\text { village }\end{array}$ & $\begin{array}{l}\text { The government must help to give } \\
\text { promotion }\end{array}$ \\
\hline & & & $\begin{array}{l}\text { The lack of attention from the } \\
\text { government on buildings in this }\end{array}$ & $\begin{array}{l}\text { The need for restoration for cultural } \\
\text { heritage buildings in this area }\end{array}$ \\
\hline
\end{tabular}




\begin{tabular}{|l|l|l|l|}
\hline & & area & \\
\hline
\end{tabular}

Source: Writer’s Analysis

In order to preserve Kampung Melayu, there must be a synergy between the government and the smallest element, meaning the Village government with local villagers. Certain strategies from the Village government are needed to foster awareness and active participation of the community to preserve the existing local culture. From the above study, strategies can be recommended to conserve Kampung Melayu Darat first is by encouraging community to re-explore the cultural values that have been abandoned. In addition, the next strategy is by maintaining the remained conventional buildings. This strategy is aimed to restore the much lost historical values of Kampung Melayu which has contribution to the formation of Semarang city. Also, maintaining traditional building architecture is important, particularly public settlement and public facilities such as worship buildings.

\section{CONCLUSION}

By tracing the historical heritage and settlement in Kampung Melayu Darat area, it is known that there is regularity and the similar pattern in traditional village structure based on certain ethnic. The classification from functional, ethnic, and livelihood sides as today is still found in Kampung Melayu Darat area in particular and in Semarang city in general.

Besides becoming one of the cultural identity of the city with cultural heritage and tourism potentials, Kampung Melayu Darat also becomes a symbol that serves to foster self-confidence, pride and foster the work ethic of the community. As mandated by Law No. 11 of 2010 on Cultural Heritage, Kampung Melayu Darat can be designated as a conservation area, which is a controlled area, because there are several buildings categorized into cultural heritage that must be preserved.

Kampung Melayu Darat as one of the conservation areas in Semarang city containing cultural heritage as well as a place to preserve and develop the existing local culture is very urge to be sought to preservation. This is related to many objects of cultural heritage that are currently in a minor until heavily damaged conditions and even destroyed without any trace.

\section{ACKNOWLEDGMENT}

Our thanks would be addressed to all people in Kampung Melayu Darat assisting our research, all the related institutions that provided the needed data and information, and also all of people who contributed to this research.

\section{REFERENCES}

Affandi, FB; Soemardi AR, 1999, Monuments and Sites Indonesia, Bandung : Icomos Indonesia \& PF Book.

Budihardjo, Eko, Arsitektur sebagai Warisan Budaya, Jakarta : Djambatan, 1997.

Ismijono,1998, Pemugaran Bangunan Kayu, Makalah Lokakarya Pengembangan Metode \& Tehnik Konservasi Bangunan Kayu.

Mastori G., 1971, Humidity in Monument, Faculty of Architecture, University of Rome, JCSPRCP, Roma.

Mundardjito, 1972, Metode Arkeologi, Kertas kerja dalam penataran tenaga ahli arkeologi.

Roesmanto, Totok, 1989, Studi Inventarisasi dan Perkembangan Arsitektur Masjid di Jawa Tengah, Semarang : DPU Cipta Karya Prop. Dati I Jawa Tengah dan PT Arsiken.

Stambolov. Tand JRJ. Van Asperen de Boer, 1976, The Deteoration and Conservation of Porous Building Material in Monument, second ed. ICSPRCP, Roma. Samidi, Archaelogical, Principles in Restoration of Wooden Archaeological Heritage.

Timbul Haryono, 1998, Metode Arkeologi Dalam Pelestarian Benda Cagar Budaya, Penataran Tenaga Teknis Kesejarahan Dan Kepurbakalaan Tingkat Lanjutan, Yogyakarta.

Waryono R., A. Rifai, \& D.H. Gunawan, 1987, Pengantar Meteorologi dan Klimatologi untuk Universitas dan Umum, PT. Bura Ilmu, Surabaya.

Wright, Arnold; Breakspear, Oliver t (ed), 1909, Twentieth Century Imprssions of Netherlands India: Its History, People Commerce, Industries, and Resources, Batavia : Lloyd's Greater Britain Publishing Company, Ltd.

Undang Undang RI No. 11 Tahun 2010 tentang Cagar Budaya, di dalam himpunan peraturan perundang undangan RI tentang Benda Cagar Budaya

\section{AUTHORS}

First Author - Suzanna Ratih Sari, Doctor, Architecture Department, Diponegoro University, Ratihsaris@yahoo.com

Second Author - Eko Punto Hendro, Doctor, Historic Science Department, Diponegoro University, Eko.Ipung@gmail.com

Third Author - Hermin Werdiningsih, Master, Architecture Department, Diponegoro University, hwerdiningsih@yahoo.co.id

Correspondence Author - Suzanna Ratih Sari, Ratihsaris@yahoo.com , 08222761892 